Vol. 1, No. 1, 2020, pp. 1-12

DOI: https://doi.org/10.29210/9930

Contents lists available at Journal IICET

Lentera Negeri

\title{
Article Coaching Clinic dalam Peningkatan Kapasitas Publikasi Illmiah Dosen di Universitas Hamzanwadi
}

\author{
Khirjan Nahdi ${ }^{* 1}$, Sitti Rohmi Djalilah ${ }^{1}$, Muhammad Djamaluddin ${ }^{1}$, Shahibul Ahyan ${ }^{1}$, \\ Samsul Lutfi ${ }^{1}$, Danang Prio Utomo ${ }^{1}$ \\ ${ }^{1}$ Universitas Hamzanwadi, Lombok, Indonesia
}

\section{Article Info \\ Article history: \\ Received Oct $21^{\text {th }} 2020$ \\ Revised Oct $30^{\text {th }} 2020$ \\ Accepted Nov $10^{\text {th }} 2020$ \\ Published Nov $30^{\text {th }} 2020$}

\section{Keyword:}

Article

Coaching Clinic

Publication

\begin{abstract}
Community Service entitled Article Coaching Clinic in Increasing the Capacity of Scientific Publications for Lecturers at Hamzanwadi University aims to improve the skills of lecturers in compiling scientific publications so that writing habits are created as an academic culture at Hamzanwadi University. This activity is carried out using the workshop method and online mentoring in accordance with the development of the articles on the results of the article clinic activities. Of the 114 articles that were submitted to this clinic, 108 of them were successfully submitted, and 85 of them were published. It was concluded that coaching clinic activities in encouraging the number of scientific publications were very strategic because the material was adapted to the needs of the journal. Furthermore, the activity continues by monitoring the progress of writing, until the article is declared ready to be submitted.
\end{abstract}

(C) 2020 The Authors. Published by IICET

This is an open access article under the CC BY-NC-SA license

(https://creativecommons.org/licenses/by-nc-sa/4.0

\section{Corresponding Author:}

Khirjan Nahdi,

ఏkhirjan.nw@gmail.com

\section{Pendahuluan}

Salah satu tugas pokok Perguruan tinggi adalah mengembangkan ilmu pengetahuan (Fauzi, Aprianto, Amiruddin, \& Zulqarnain, 2020). Tugas tersebut direalisasikan melalui pengkajian dan risetriset ilmiah yang dilakukan oleh komunitas akademik yang terdapat di dalamnya, terutama para dosen. Berdasarkan surat Dikti Nomor 152/E/T/2012 yang mengharuskan setiap pelaku di dunia pendidikan tinggi, untuk melakukan publikasi penelitian, baik dalam bentuk jurnal nasional maupun jurnal intemasional (Dikti, 2010; Djunaedi, 2015). Hal ini merupakan salah satu upaya pemerintah untuk terus meningkatkan mutu pendidikan tinggi di Indonesia, agar dapat bersaing secara internasional. Sebagai profesional, dosen dituntut memiliki serangkaian kemampuan agar dapat melaksanakan tugasnya dengan optimal (Nayyif Sujudi, 2020; Wibawa, Kurniawati, \& Hardiansyah, 2020). Salah satunya adalah dalam melakukan penelitian dan publikasi karya tulis ilmiah yang baik (Nugrohoadhi, 2017; Panjehpour \& Sorooshian, 2019)

Tujuan penyusunan karya tulis ilmiah, seperti melaporkan hasil penelitian, menemukan jawaban atas pertanyaan penelitian, membahas subjek yang akan ditulis, dan menemukan sintesis dari variabel yang akan dikaji (Snyder, Foltz, Lendner, \& Vaccaro, 2019). Jika disederhanakan, Keempat tujuan penyusunan karya tulis ilmiah menjadi dua kategori karya tulis ilmiah, yakni karya tulis ilmiah hasil penelitian dan hasil ulasan atau gagasan ilmiah (Alajami, 2020; Kristanto, 2018). Temuan melalui kedua jenis karya tulis ilmiah ini perlu dipublikasikan sebagai ajang diskusi, berbagi informasi, dan menambah wawasan ilmiah 
bagi pihak lain (Darmalaksana \& Suryana, 2018; Farid, 2017). Salah satu bentuk publikasi ilmiah adalah artikel. Menurut keduanya, artikel ilmiah dipublikasikan dengan harapan menginspirasi peneliti dan pengulas lain, sehingga melakukan hal yang sama dalam mengembangkan ilmu pengetahuan (Puljak \& Sambunjak, 2020; Rumisek \& Zemach, 2003). Tentu saja, artikel ilmiah yang baik dan menginspirasi adalah artikel yang memiliki daya kritis dan struktur argumen yang dapat diterima secara ilmiah (Eddy, 2020; Mahendra \& Dewi, 2017).

Artikel sebagai salah satu publikasi ilmiah menjadi salah satu indikator keilmuan dan kapasitas akademik dosen, sebagaimana diatur dalam Pedoman Operasional Penilaian Angka Kredit Kenaikan Jabatan Akademik/Pangkat Dosen (PO 2019) (Ristekdikti, 2019; Weinstein, 2020). Dalam pedoman tersebut, setiap dosen dipersyaratkan memiliki publikasi ilmiah pada jurnal kredibel sebagai bukti pelaksanaan Tri Dharma Perguruan Tinggi sesuai jabatan akademiknya. Pemenuhan persyaratan tersebut sebagai bukti kapasitas intelektual dosen sehingga layak sebagai agen ilmu pengetahuan dalam tanggung jawab sebagai dosen (Botea \& Popescu, 2020b; Nugrohoadhi, 2017). Publikasi ilmiah, sebagaimana dikatakan tidak saja menyiapkan data dan simpulan kajian, tetapi mendorong proses argumentasi logis dan intelektualitas melalui relasi teori dan fakta untuk sampai pada suatu simpulan (Sasson, et al., 2020; Whang, 2020). Karena itu, selain sebagai hajat menaikkan jenjang akademik, publikasi ilmiah bagi dosen adalah proses pergumulan keilmuan secara terus menerus dalam kapasitasnya sebagai agen ilmu pengetahuan sehingga memiliki kelayakan pada mimbar akademik secara bebas dan bertanggung jawab (Bailey, 2003; Gopee \& Deane, 2013). Dari segi fisik, tampilan publikasi ilmiah relatif baku, sehingga mudah untuk dilakukan Walaupun mudah, publikasi ilmiah dalam bentuk apa pun, termasuk artikel ilmiah tidak mungkin hadir secara serta merta (Botea \& Popescu, 2020b; Reis, 2020). Artinya, semua harus berproses mengikuti strategi dan tahapan baku tersebut. Strategi dan tahapan dalam maksud ini tidak dibedakan secara ketat, karena tampil secara bersamaan dalam proses penyusunan bahan publikasi (Botea \& Popescu, 2020a; Lisek, 2020). Tahapan menentukan jenis publikasi berdasarkan penelitian atau ulasan, batasan artikel dalam satu bidang ilmu, kejelasan tujuan, efektivitas metode, akurasi data dan analisis, hingga ketepatan simpulan, tahapan dan strategi dalam penyiapan bahan publikasi ilmiah (Busse \& August, 2020; Weinstein, 2020).

Untuk memenuhi kapasitas sesuai ketentuan PO 2019 dan pembiasaan para dosen di Universitas Hamzanwadi terhadap seluruh tahap dan strategi penyusunan bahan publikasi ilmiah. Karena itu, kegiatan article coaching clinic dilaksanakan dalam rangka: 1) meningkatkan keterampilan para dosen dalam menyusun bahan publikasi ilmiah, baik berdasarkan hasil penelitian maupun ulasan; 2) menciptakan iklim akademik yang diwarnai oleh kebiasaan menulis ilmiah sebagai pembuktian kapasitas sebagai agen ilmu pengetahuan sehingga layak melakukan mimbar akademik secara bebas. Agenda ini sangat urgen dalam memenuhi indikator proses dan ouput dalam annual clustering perguruan tinggi sebagai indikator kinerja Tri Dharma Perguruan Tinggi.

\section{Metode}

Program Article Coaching Clinic ini merupakan agenda lanjutan dari Hamzanwadi International Conference on Technology and Education (HICTE) tahun 2019, sebagai salah satu Annual International Conference yang diselenggarakan sejak tahun 2014. Coaching Clinic ini diorganisir dalam bentuk workshop dan pendampingan, dengan tahapan sebagaimana pada tabel 1 di bawah ini.

Tabel 1: Agenda Workshop dan Pendampingan

\begin{tabular}{llllll}
\hline No. & Kegiatan & Hasil diharapkan & Metode & Tim Pendamping Jadual \\
\hline 1 & Koordinasi & Ada publisher & Kontrak & Tim Indonesian Nopember \\
& Publisher & internasional yang & kemitraan & Institute for 2019 \\
& menjadi media & Penerbitan artikel & Counseling & \\
& publikasi artikel yang & & Education and \\
& ikut Coaching Clinic & & Therapy (IICET) \\
& & & Padang, Sumatera \\
& & & Barat dan Tim \\
& & & Relawan Jurnal \\
& & & Indonesia (RJI) \\
& & & Regional NTB \\
\hline
\end{tabular}




\begin{tabular}{|c|c|c|c|c|c|}
\hline 2 & $\begin{array}{l}\text { Seleksi Artikel } \\
\text { Presentasi } \\
\text { HICTE } 2019\end{array}$ & $\begin{array}{l}\text { Diperoleh artikel } \\
\text { yang layak ikut } \\
\text { program Article } \\
\text { Coaching Clinic }\end{array}$ & $\begin{array}{l}\text { Revieu untuk } \\
\text { kesesuaian dengan } \\
\text { Publisher: } \\
\text { Template, Title, } \\
\text { content, method, } \\
\text { hasil dan diskusi, } \\
\text { simpulan, dan } \\
\text { referensi }\end{array}$ & $\begin{array}{lr}\text { Tim } & \text { Editor } \\
\text { Indonesian Institute } \\
\text { for Counseling } \\
\text { Education } \text { and } \\
\text { Therapy } \\
\text { Padang, Sumatera } \\
\text { Barat dan Tim } \\
\text { Relawan } & \text { Jurnal } \\
\text { Indonesia } & \text { (RJI) } \\
\text { Regional NTB }\end{array}$ & $\begin{array}{l}\text { Nopember } \\
2019\end{array}$ \\
\hline & $\begin{array}{l}\text { Article } \\
\text { Coaching } \\
\text { Clinic }\end{array}$ & $\begin{array}{l}\text { Peserta mampu } \\
\text { menulis artikel sesuai } \\
\text { standar publisher } \\
\text { internasional }\end{array}$ & $\begin{array}{l}\text { Workshop dalam } \\
\text { kelas: novelties, } \\
\text { template, citasi, } \\
\text { dan submitted }\end{array}$ & $\begin{array}{lr}\text { Tim } & \text { Editor } \\
\text { Indonesian Institute } \\
\text { for Counseling } \\
\text { Education and } \\
\text { Therapy } \\
\text { Padang, Sumatera } \\
\text { Barat dan Tim } \\
\text { Relawan } & \text { Jurnal } \\
\text { Indonesia } & \text { (RJI) } \\
\text { Regional NTB }\end{array}$ & $\begin{array}{l}\text { Desember } \\
2019\end{array}$ \\
\hline & $\begin{array}{l}\text { Pendampingan } \\
\text { Pasca } \\
\text { Workshop }\end{array}$ & $\begin{array}{l}\text { Diperoleh artikel } \\
\text { yang siap submitted } \\
\text { setelah mengalami } \\
\text { tahapan revisi }\end{array}$ & $\begin{array}{l}\text { Korespondensi } \\
\text { online individual }\end{array}$ & $\begin{array}{l}\text { Tim Editor } \\
\text { Indonesian Institute } \\
\text { for Counseling } \\
\text { Education and } \\
\text { Therapy (IICET) } \\
\text { Padang, Sumatera } \\
\text { Barat dan Tim } \\
\text { Relawan Jurnal } \\
\text { Indonesia (RJI) }\end{array}$ & $\begin{array}{l}\text { Januari } \\
\text { Maret } \\
2020\end{array}$ \\
\hline
\end{tabular}

\section{Hasil dan Pembahasan}

\section{Kegiatan Pendahuluan (HICTE) 2019}

Article Coaching Clinic diadahului dengan agenda Hamzanwadi International Conference on Technology and Education (HICTE) tahun 2019. Kegiatan ini dilaksanakan pada Tanggal 5 Oktober 2019 dengan menampilkan 5 keynote speakers dari 5 negara, yakni Dr. Trudy Sweeney (Flinders University, Australia); Dr. Meechooke Chodoung (Chulalongkorn University); Prof. Zainal Arifin Hasibuan, MLS., Ph.D. (Universitas Indonesia); Dr. L. Sivarama Krishna (Indian Institute of Technology Roorkee, India); Vinay Kumar, Ph.D. (Chulalongkorn University); dan Assoc. Prof. Ts. Dr Wan Mohd Khairul Wan Mohamed Zin (University Malaysia Trengganu). Kelima makalah inti diikuti dengan 145 pendamping dari berbagai perguruan tinggi di Indonesia.

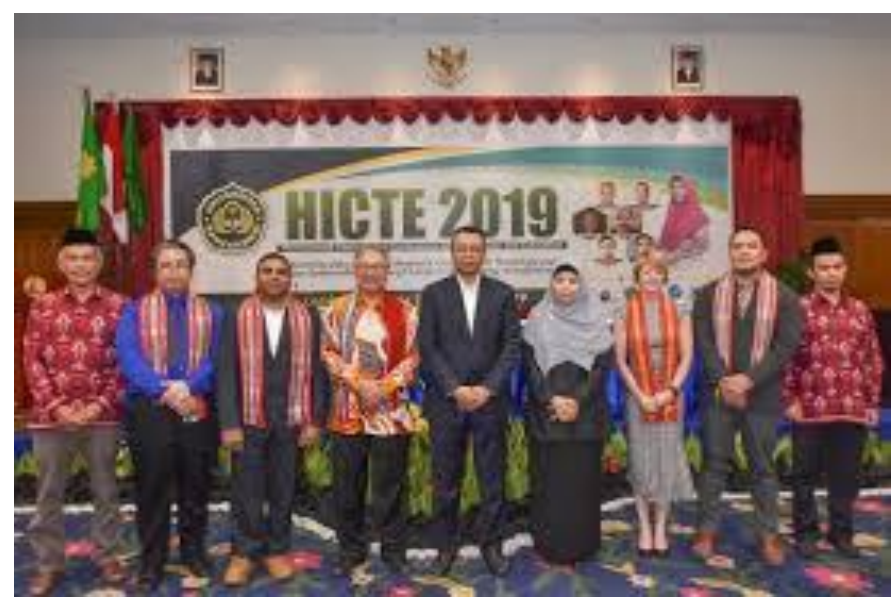

Gambar 1. Kegiatan HICTE 2019 


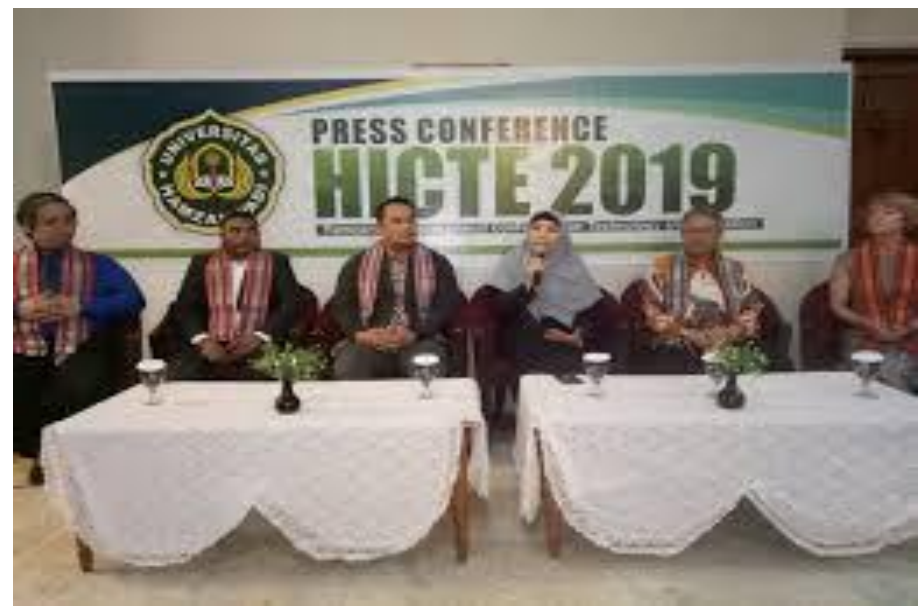

Gambar 2. Siaran Pers Rektor Universitas Hamzanwadi bersama Keynote Speakers

\section{Koordinasi Publisher dan Seleksi Artikel}

Koordinasi publisher dimaksudkan untuk memperoleh kesepakatan publisher yang sesuai dengan tema dan scope artikel publikasi hasil Article Coaching Clinic. Melalui diskusi yang intens dilakukan kesepakatan dengan Institute of Physics Publishing (IOP) untuk tema-tema teknologi dan science, dan Atlantis Press untuk tema-tema Sosial Humaniora. Dari 145 artikel yang dipresentasikan di HICTE 2019, 114 di antaranya dinyatakan layak ikut dalam kegiatan Article Coaching Clinic.

Pelaksanaan Coaching Clinic, Pendampingan dan Artikel Siap Submitted

Kegiatan Article Coaching Clinic dilaksanakan selama 30 Jam Pelatihan, dengan agenda sebagaimana pada tabel 2.

Tabel 2. Struktur Program Article Coaching Clinic

\begin{tabular}{|c|c|c|c|c|}
\hline No. & Materi & Fasilitator & Hasil & $\begin{array}{l}\text { Jam } \\
\text { Pelatihan } \\
\text { (JP) }\end{array}$ \\
\hline 1 & Pengantar Pembukaan & $\begin{array}{l}\text { Wakil Rektor Bidang } \\
\text { Akademik }\end{array}$ & $\begin{array}{l}\text { Penjelasan tujuan, proses, dan } \\
\text { luaran kegiatan }\end{array}$ & $1 \mathrm{JP}\left(45^{\prime}\right)$ \\
\hline 2 & $\begin{array}{l}\text { Overview Rank Sinta } \\
\text { dan GS Universitas } \\
\text { Hamzanwadi dan } \\
\text { kontribusinya } \\
\text { terhadapa kapasitas } \\
\text { institusi }\end{array}$ & $\begin{array}{l}\text { Ifdil, Ph.D. M. Pd. } \\
\text { Kons. }\end{array}$ & $\begin{array}{l}\text { Posisi Universitas } \\
\text { Hamzanwadi pada rank } 603 \\
\text { nasional untuk seluruh tahun, } \\
\text { rank } 394 \text { untuk } 3 \text { tahun } \\
\text { terkahir (2016-2018). Masih } \\
\text { belum berimbang dengan } \\
\text { jumlah } 254 \text { dosen memiliki } \\
\text { akun Sinta dan GS. }\end{array}$ & 3 JP (135') \\
\hline 3 & $\begin{array}{l}\text { Mengenal ciri topik, } \\
\text { novelties dalam } \\
\text { struktur artikel yang } \\
\text { lazim sesuai dengan } \\
\text { editor jurnal dan } \\
\text { reviewer artikel }\end{array}$ & $\begin{array}{l}\text { Ifdil, Ph.D. M. Pd. } \\
\text { Kons. }\end{array}$ & $\begin{array}{l}\text { Teridentifikasi } 114 \text { topik } \\
\text { artikel HICTE } 2019 \text { setelah } \\
\text { dilakukan perbaikan sesuai } \\
\text { dengan penjelasan Fasilitator } \\
\text { yang diangap layak masuk } \\
\text { pada kegiatan article coaching } \\
\text { clinic }\end{array}$ & $6 \mathrm{JP}\left(270^{\prime}\right)$ \\
\hline 4 & $\begin{array}{l}\text { Class Coaching Clinic } \\
\text { 1. Hasil Penelitian } \\
\text { jadi artikel } \\
\text { 2. Menyesuaikan } \\
\text { template Jurnal } \\
\text { 3. Model Sitasi }\end{array}$ & TIM IICET & $\begin{array}{l}\text { 1. Hilirisasi artikel dari hasil } \\
\text { penelitian dan hasil } \\
\text { ulasan/opini } \\
\text { 2. Menyesuaikan Komponen } \\
\text { artikel mulai dari judul } \\
\text { hingga referensi dengan } \\
\text { maksud petunjuk template }\end{array}$ & $\begin{array}{l}20 \mathrm{JP} \\
\left(900^{\prime}\right)\end{array}$ \\
\hline
\end{tabular}




\begin{tabular}{|c|c|c|c|c|c|}
\hline & & & 3. & $\begin{array}{l}\text { artikel. Karena kemitraan } \\
\text { publisher dengan IOP } \\
\text { Publishing dan Atlantis } \\
\text { Press, } 114 \text { harus } \\
\text { disesuaikan dengan } \\
\text { keduanya } \\
\text { Semua artikel } \\
\text { menggunakan sitasi } \\
\text { Mendeley }\end{array}$ & \\
\hline 5 & Pendampingan online & Tim IICET & 1. & $\begin{array}{l}3 \text { kali revisi untuk } 114 \\
\text { artikel } \\
\text { Pada } 3 \text { kali revisi, } 87 \\
\text { artikel layak submitted ke } \\
\text { IOP dan } 14 \text { artikel layak } \\
\text { submitted ke Atlantis } \\
\text { Press, dan } 8 \text { lainnya } \\
\text { disiapkan menuju IJICC }\end{array}$ & 2 bulan \\
\hline
\end{tabular}

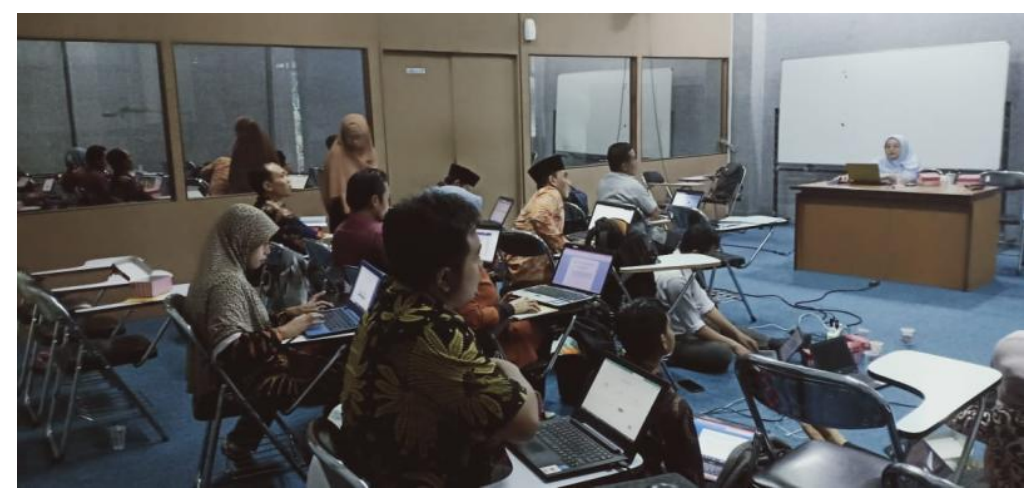

Gambar 3. Pelakasanaan Coaching Clinic

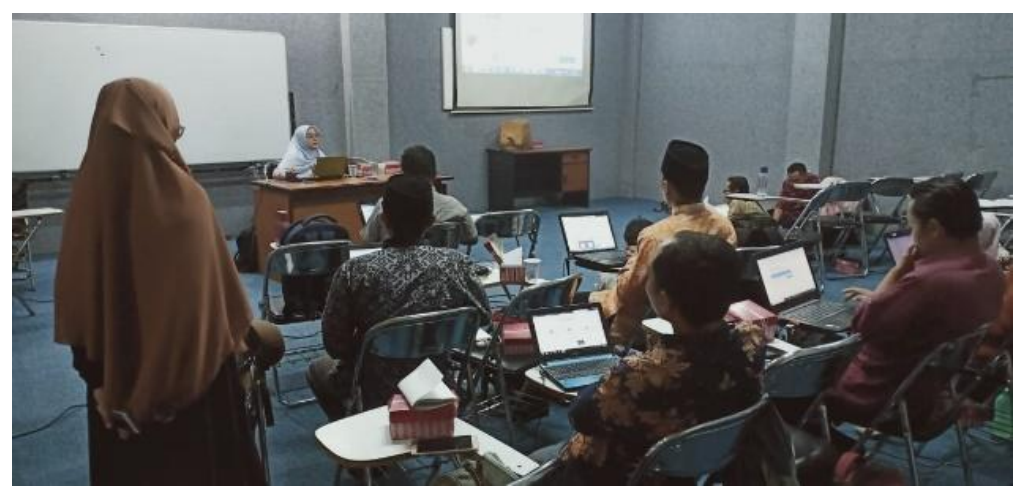

Gambar 4. Pelakasanaan Coaching Clinic 


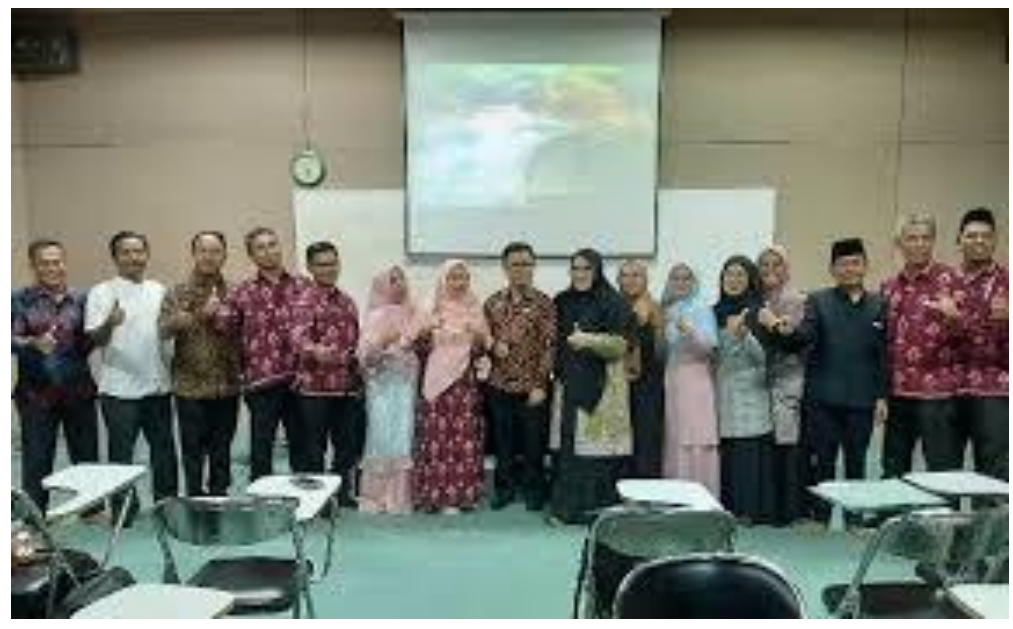

Gambar 5. Pelaksanaan Coaching Clinic

\section{Artikel Submitted dan Terpublikasi}

Setelah melalui tahapan Coaching Clinic dan pendampingan, dari 114 artikel, 87 artikel submitted ke IOP, 13 artikel sumitted ke Atlantis Press, dan 8 artikel submitted ke IJICC, sebagaimana pada tabel 3, 4, dan 5.

Tabel 3. Artikel Submitted IOP

\begin{tabular}{|c|c|c|}
\hline $\begin{array}{l}\text { Nomor } \\
\text { Urut }\end{array}$ & $\begin{array}{l}\text { Nama Penulis } \\
\text { Pertama }\end{array}$ & Judul Artikel \\
\hline 1 & $\begin{array}{l}\text { Wiwit Pura } \\
\text { Nurmayanti }\end{array}$ & $\begin{array}{l}\text { Multidimensional Scaling for Cosmetic Positioning among Students of } \\
\text { Universitas Hamzanwadi }\end{array}$ \\
\hline 2 & $\begin{array}{l}\text { Lalu Erpan } \\
\text { Suryadi }\end{array}$ & $\begin{array}{l}\text { Identificaion of Sport Talents with The Sport Search Metodhs at SDN } 1 \\
\text { Rempung in } 2019\end{array}$ \\
\hline 3 & Huzain Jailani & $\begin{array}{l}\text { Development of Inquiry Based Learning Model Based on Discussion and } \\
\text { Contextual Group Discussion to Improve Student Learning Outcomes in } \\
\text { Economics Subjects }\end{array}$ \\
\hline 4 & $\begin{array}{l}\text { Doni Septu } \\
\text { Marsa Ibrahim }\end{array}$ & $\begin{array}{l}\text { Realistic Mathematics Learning Model Through Traditional Game on } \\
\text { Primary Students }\end{array}$ \\
\hline 5 & Laxmi Zahara & $\begin{array}{l}\text { The Implementation of Cooperative Type of STAD and Hands on } \\
\text { Activity on Student Achievement }\end{array}$ \\
\hline 6 & Yahya & $\begin{array}{l}\text { Determination of Granting Appropriateness Credit at "Daruzzakah } \\
\text { Rensing" } \\
\text { Cooperative Using the Support Vector Machine (SVM) Algorithm }\end{array}$ \\
\hline 7 & $\begin{array}{l}\text { Rifa'atul } \\
\text { Mahmudah }\end{array}$ & Advancing Learning Math Industry Era 4.0 \\
\hline 8 & Indra Gunawan & $\begin{array}{l}\text { Implementation Internet of Things (IoTs) to Monitoring Temperature } \\
\text { Oven Tobacco System in East Lombok Farmers Towards } 4.0 \text { Industry }\end{array}$ \\
\hline 9 & $\begin{array}{l}\text { Yosi Nur } \\
\text { Kholisho }\end{array}$ & $\begin{array}{l}\text { The Development of Augmented Reality for Hardware Introduction for } \\
\text { SDU Hamzanwadi Students }\end{array}$ \\
\hline 10 & Zainul Muttaqin & $\begin{array}{l}\text { The Development of Indonesian Language Learning Model through } \\
\text { Puppet Creation Media }\end{array}$ \\
\hline 11 & $\begin{array}{l}\text { Muhammad } \\
\text { Rapii }\end{array}$ & $\begin{array}{l}\text { Development of economic module based on teaching and learning } \\
\text { contextual in improving student learning outcomes }\end{array}$ \\
\hline 12 & Yuyun Febriani & $\begin{array}{l}\text { Determination of Ethanol in a Distillate Sample of Arenga pinnata by } \\
\text { UV-Visible Spechtrophotometry }\end{array}$ \\
\hline
\end{tabular}




\begin{tabular}{|c|c|c|}
\hline 13 & M. Adib Nazri & $\begin{array}{l}\text { EFL Students' Ability in Answering TOEFL Reading Comprehension } \\
\text { Section }\end{array}$ \\
\hline 14 & Zuhut Ramdani & $\begin{array}{l}\text { Importance Performance Analysis: Student Satisfaction of Facilities in the } \\
\text { Classroom }\end{array}$ \\
\hline 15 & $\begin{array}{l}\text { Siti Arni } \\
\text { Wulandya }\end{array}$ & $\begin{array}{l}\text { Decision Rules on Damaged House Data for Natural Disasters Using the } \\
\text { If-Then Method Of The Rough Set Theory }\end{array}$ \\
\hline 16 & Hariman Bahtiar & $\begin{array}{l}\text { Mobile Based Geographic Information System for mapping and data } \\
\text { collection of Nahdlatul Wathan Schools Towards } 4.0 \text { Industry }\end{array}$ \\
\hline 17 & $\begin{array}{l}\text { Rasyid Hardi } \\
\text { Wirasasmita }\end{array}$ & $\begin{array}{l}\text { Maximizing Computer Based Test (CBT) Teslet Model } \\
\text { for Education Quality Mapping }\end{array}$ \\
\hline 18 & Baiq Mahyatun & $\begin{array}{l}\text { Application of online conseling services in facing competition asean } \\
\text { economic community in higher education }\end{array}$ \\
\hline 19 & Marfuatun & $\begin{array}{l}\text { Development of Educative Snake Media To Improve Career Planning } \\
\text { Ability Through Group Counseling For Students MTs. NW No. } 1 \text { Talun } \\
\text { Academic Year 2019/2020 }\end{array}$ \\
\hline 20 & $\begin{array}{l}\text { Baiq Desi Dwi } \\
\text { Arianti }\end{array}$ & $\begin{array}{l}\text { WILMO (Web-based Interactive Learning Module), E-learning Design } \\
\text { for Vocational School }\end{array}$ \\
\hline 21 & $\begin{array}{l}\text { Baiq Liana } \\
\text { Widiyanti }\end{array}$ & Assessing Environmental Sanitation Knowledge of University Students2 \\
\hline 22 & Susilawati & $\begin{array}{l}\text { The Impact Analysis of Social Media Facebook on The Education } \\
\text { Patterns of Elementary School Children }\end{array}$ \\
\hline 23 & Ramli Ahmad & IOT Base Household Equipment Control Using Arduino and Smartphone \\
\hline 24 & HASRUL HADI & $\begin{array}{l}\text { Implementation of Discovery Based Learning and Talking Chips to } \\
\text { Improve Attitudes Appreciating the Others Opinion on Geography } \\
\text { Learning }\end{array}$ \\
\hline 25 & zulfadli hamdi & $\begin{array}{l}\text { Influence of Psycho-Linguistic-Based Game Methods Towards Indonesia } \\
\text { Language Speaking Skills }\end{array}$ \\
\hline 26 & $\begin{array}{l}\text { Baiq Andriska } \\
\text { Candra Permana }\end{array}$ & $\begin{array}{l}\text { Design And Development Of Automotive Workshop Application Based } \\
\text { On Android And IOS Using Dart Programming Language }\end{array}$ \\
\hline 27 & $\begin{array}{l}\text { muh.iman } \\
\text { darmawan }\end{array}$ & $\begin{array}{l}\text { Study Fabrication Dye Sensitized Solar Cells Using The Combined } \\
\text { Organic Polymer Poly (3-Hexylthiophene) P3HT With Extracts Dye } \\
\text { Natural Organic }\end{array}$ \\
\hline 28 & Muhamad Sadali & $\begin{array}{l}\text { Evaluation Of Lecturer Education And Teaching Performance Through } \\
\text { E-Monevin Using K-Nearest Neighbor (K-NN) Algorithm }\end{array}$ \\
\hline 29 & $\begin{array}{l}\text { B. Fitri } \\
\text { Rahmawati }\end{array}$ & Learning by Google Classroom in Students' Perception \\
\hline 30 & Nila Hayati & $\begin{array}{l}\text { Learning Device Development with Cooperative Model of Productive } \\
\text { Creative Type to Improve Student's Motivation }\end{array}$ \\
\hline 31 & $\begin{array}{l}\text { Amri Muliawan } \\
\text { Nur }\end{array}$ & $\begin{array}{l}\text { Implementation of Naive Bayes Algorithm in Analyzing Acceptance of } \\
\text { Poor Student Assistance }\end{array}$ \\
\hline 32 & Rohyana Fitriani & The Influence of Gadget On Early Childhood \\
\hline 33 & Basransyah & $\begin{array}{l}\text { Application of Pyrolysis Technology as an Effort to Reduce Plastic Waste } \\
\text { in Pananjung Beach Tourism Area }\end{array}$ \\
\hline 34 & Dina Fadilah & $\begin{array}{l}\text { Increased student interest in learning through the application of active } \\
\text { learning methods in the thematic learning of fifth-grade elementary } \\
\text { schools }\end{array}$ \\
\hline
\end{tabular}




\begin{tabular}{|c|c|c|}
\hline 35 & $\begin{array}{l}\text { Wawan } \\
\text { Muliawan }\end{array}$ & $\begin{array}{l}\text { Effectiveness of Biology Learning Using Cooperative Learning Methods } \\
\text { Type TPS (Think, Pair, Share) Against Student Achievement in Class } \\
\text { VIII MTs NW Korleko Academic Year 2019/2020 }\end{array}$ \\
\hline 36 & Marhamah & $\begin{array}{l}\text { The Influence of Problem Based Learning Model using Lesson Study } \\
\text { Patterns on Creative Thinking Ability of Students }\end{array}$ \\
\hline 37 & $\begin{array}{l}\text { MUHAMMAD } \\
\text { SAIFUL }\end{array}$ & $\begin{array}{l}\text { Application of Expert System with Web-Based Forward Chaining } \\
\text { Method in Diagnosing Corn Plant Disease }\end{array}$ \\
\hline 38 & Rina Nopiana & $\begin{array}{l}\text { The Influence of Using Video Media On Basic Movement Skills Lay-Up } \\
\text { Shoot Basketball }\end{array}$ \\
\hline 39 & SURYANSAH & $\begin{array}{l}\text { Use of Information Technology Media on Physical Activities of Students } \\
\text { of Sman } 1 \text { Mantang }\end{array}$ \\
\hline 40 & Sri Supiyati & $\begin{array}{l}\text { Ethnomathematic of Sasaknese As A Mathematic Learning Source at } \\
\text { Elementary Education }\end{array}$ \\
\hline 41 & Atiaturrahmaniah & $\begin{array}{l}\text { Using fractional card media and math games to increase students' } \\
\text { activities and learning outcomes }\end{array}$ \\
\hline 42 & Mahpuz & $\begin{array}{l}\text { Visualization of The Traditional House Architecture Of Belek Sembalun } \\
\text { Lawang } \\
\text { Village By Using 3D Animation }\end{array}$ \\
\hline 43 & Suhirman & $\begin{array}{l}\text { Information and Communication Technology (ICT) In the scope of } \\
\text { development of children aged 5-6 years in the Seruni Selong Environment }\end{array}$ \\
\hline 44 & $\begin{array}{l}\text { nur adiyah } \\
\text { yuliastri }\end{array}$ & $\begin{array}{l}\text { The Impact of Wonder Share Quis Creator Application to Improve } \\
\text { Cognitive Abilities of Children 5-6 Year. }\end{array}$ \\
\hline 45 & Ahmad Rasidi & $\begin{array}{l}\text { The influence of PAIKEM GEMBROT model against student's self } \\
\text { efficacy and learning outcomes }\end{array}$ \\
\hline 46 & fartina & $\begin{array}{l}\text { Development of Interactive Physics Learning Media Macromedia Flash } 8 \\
\text { Based on Straight Motion Material }\end{array}$ \\
\hline 47 & Aris Sudianto & $\begin{array}{l}\text { Website as Foundation Information Media under the auspices of } \\
\text { Nahdlatul Wathan, in West Nusa Tenggara Province }\end{array}$ \\
\hline 48 & Edy Waluyo & $\begin{array}{l}\text { Implementation Problem Based Learning in Improving Activities and } \\
\text { Critical Thinking Skill }\end{array}$ \\
\hline 49 & Neny Endriana & $\begin{array}{l}\text { Model Development Project Based Learning to Improve Mathematical } \\
\text { Reasoning and Motivation }\end{array}$ \\
\hline 50 & irwan rahadi & Red blood cells and white blood cells detection by image processing \\
\hline 51 & Nuraini & $\begin{array}{l}\text { Development of Science Learning with Project Based Learning on } \\
\text { Science Process Skill in East Lombok: ANeeds Analysis Study }\end{array}$ \\
\hline 52 & $\begin{array}{l}\text { Ari } \\
\text { Prasetyaningrum }\end{array}$ & $\begin{array}{l}\text { An Analysis on Grammatical Errors in } \\
\text { Writing Descriptive Paragraph for EFL Learner }\end{array}$ \\
\hline 53 & M. Deni Siregar & $\begin{array}{l}\text { Decreased Anxiety Level of MTs NW Perian Students } \\
\text { Through Spiritual Therapy and Game Engineering Techniques }\end{array}$ \\
\hline 54 & Abdul Hafiz & $\begin{array}{l}\text { The Implications of Technological Media Towards the Social Life of } \\
\text { Aikmel Community of Aikmel District East Lombok }\end{array}$ \\
\hline 55 & Hartini Haritani & $\begin{array}{l}\text { The Influence of the Guided Inquiry Learning Model on the Creative } \\
\text { Thinking Capability }\end{array}$ \\
\hline 56 & $\begin{array}{l}\text { Nunung } \\
\text { Ariandani }\end{array}$ & $\begin{array}{l}\text { The Effect of Project-Based Learning Model Using Three Dimentional } \\
\text { Media And Computation On Achievement Of Study Reviewed From }\end{array}$ \\
\hline
\end{tabular}


Student Creativity In Material Of Molecular Shape

$57 \quad$ Saprudin Jauhari

$58 \quad$ Muhammad Gazali

59 Suhartini

$60 \quad$ Muhammad Wasil

61 Syahrul Amar

62 Muhammad Zamroni Uska

Herman Afrian

Sururuddin

Duka Yunitasari

farhana muhammad

Hirzi

Kholida Ismatulloh
Influence of integrative learning model based on lesson study in reading comprehension ability for five grade students of sdn 3 sakra

The Comparison of Cooperative Learning Method of Rotating Trio Exchange Type and Think Pair Share Type

Web-Based Expert System to Detecte Chili Desease Using Rule Base Reasoning Approach

Application of the Decision Tree Method to Predict Grade XII Student Achievements Viewed from Final Semester Values in Madrasa Aliyah (MA) NW Rempung

The Pinisi: A Study on the Development of Boat Technology

The application of Usability Testing Method for Evaluating the New Student Acceptance (NSA) System

The Influence of AudioVisual Based Learning Media on Learning Temboyak Dance

Idenatification of Sports Talent (Using Sport Search) in Students of State Middle School

Carrying capacity water control procedures of land use changes in sub watershed Cimanuk upstream using GIS (Geographic Information System)

The Analysis on Factor Determining in Unsustainable English Learning at Hamzanwadi University

Analysis of Factors Affecting Student Interest to Continue Study to SMK

Analysis of Playing Online Games On Children's Aggressiveness In Jero Gunung Village, Sakra Barat

Read Fast Through Skimming Techniques on Class 3 MI Hamzanwadi No. 1 Pancor Lombok Timur

Development of learning media base on e-Elearning towards student learning result at $\mathrm{pkbm}$ al halimi academic

Increasing the Students' ability of High Order Thinking Skill (HOTS) By Implementing of blended learning

Ethnomathematic Worksheet by Scientific Aproach

The Application of Probing Prompting Method in Physic Courses in the Second Semester of Informatics Education

Comparison of Pso-Based Naive Bayes And Naive Bayes Algorithm in Determining the Feasibility of Bumdes Credit in Village Gerung Permai Suralaga District East Lombok Regency

Adaptive Thresholding Algorithms and Morphological to Improve the Quality of Takepan Sasak Image Readability

Problem-based learning of teaching aids Development "linear program board" in improving student learning outcomes

Dropout School Children in Coastal Communities

Application of K-Nearest Neighbor Algorithm for Classification of Mental Disabilities Patients Based on Age in Selong District, East Lombok Regency 


\begin{tabular}{|c|c|c|}
\hline 79 & $\begin{array}{l}\text { Baiq Desi Dwi } \\
\text { Arianti }\end{array}$ & $\begin{array}{l}\text { The Development of E-Learning Use MOODLE as A Multimedia } \\
\text { Learning Medium in Vocational School }\end{array}$ \\
\hline 80 & Alimuddin & $\begin{array}{l}\text { Implementation of the Neural Network (NN) Algorithm in Analysis of } \\
\text { Student Class Increment Data Based on Report Card Value. }\end{array}$ \\
\hline 81 & Siti Maysuroh & An Analysis of Students' Writing Anxiety Experienced by EFL Students \\
\hline 82 & $\begin{array}{l}\text { Muhammad } \\
\text { Djamaluddin }\end{array}$ & $\begin{array}{l}\text { Normalization of Facial Pose and Expression to Increase the Accuracy of } \\
\text { Face Recognition System }\end{array}$ \\
\hline 83 & Taufik Akbar & $\begin{array}{l}\text { Prototype System of Temperature and Humadity Automatic in Oyster } \\
\text { Mushroom Cultivation using Arduino Uno }\end{array}$ \\
\hline 84 & Rody Satriawan & $\begin{array}{l}\text { The Card Logic Logarithm as an Interactive Media in Teaching } \\
\text { Logarithm: A Development Study of Mathematics Education }\end{array}$ \\
\hline 85 & Pahrudin & $\begin{array}{l}\text { The implementation of cooperative learning through lesson study to } \\
\text { improve students' autonomous learning in the } 21 \text { st century. }\end{array}$ \\
\hline 86 & $\begin{array}{l}\text { Indra Himayatul } \\
\text { Asri }\end{array}$ & $\begin{array}{l}\text { The Influence of Two Stay Two Stray (TS-TS) Cooperative Model on } \\
\text { Problem Solving Ability in Class VII at Junior High School }\end{array}$ \\
\hline 87 & $\begin{array}{l}\text { Najamuddin } \\
\text { Amy }\end{array}$ & $\begin{array}{l}\text { Management of Issue and Public Trust in West Nusa Tenggara Province } \\
\text { Using Information Technology }\end{array}$ \\
\hline
\end{tabular}

Tabel 4. Artikel Submitted Atlantis Press

\begin{tabular}{lll}
\hline $\begin{array}{l}\text { Nomor } \\
\text { Urut }\end{array}$ & $\begin{array}{l}\text { Nama Penulis } \\
\text { Pertama }\end{array}$ & Judul Artikel \\
\hline 1 & Nopi Hariadi & $\begin{array}{l}\text { Contribution of Training Variations to Improving Basic Skills in } \\
\text { Playing Futsal }\end{array}$ \\
2 & Khirjan Nahdi & $\begin{array}{l}\text { Critical Discourse Analysis of Transparency of Information and } \\
\text { Online Transactions as Triggers for Early Marriage for Millennial } \\
\text { Women }\end{array}$ \\
3 & Muh. Yazid & $\begin{array}{l}\text { Improve Learning with Moving Images } \\
\text { Effectiveness of Entrepreneurship Instructions in Order to }\end{array}$ \\
4 & Muh. Fahrurrozi & $\begin{array}{l}\text { Enhance Post Migration Indonesian Migrant Workers' } \\
\text { Entrepreneurial Independence }\end{array}$ \\
5 & Policy on Internal Quality Assurance System \\
7 & Mudarman & $\begin{array}{l}\text { Variation Rate of the Value Sense of English Language the Sasak } \\
\text { People In the village Gereneng Subdistrict East Sakra }\end{array}$ \\
8 & Sandy Ramdhani & $\begin{array}{l}\text { Developing Skills Teachers Early Childhood Through Tales } \\
\text { Writing Training and Presentation Techniques East Lombok }\end{array}$ \\
9 & Hary Murcahyanto & Vocal Technique of The Keroncong Song Ahlan Wa Sahlan \\
10 & Muzakki & $\begin{array}{l}\text { Impact of Zonation Policy in Receiving New Students (PPDB) } \\
\text { Study of State 1 Pringgasela District, East Lombok District, each } \\
\text { Year 2018/2019 }\end{array}$ \\
& & Tuan Guru A Leader of Rural Education Development \\
12 & Aswasulasikin & Diversity Seagrass in Pink Beach Lombok \\
13 & Husnayati Hartini &
\end{tabular}


Tabel 5. Artikel Submitted ke IJICC

\begin{tabular}{|c|c|c|c|}
\hline No. & Nama & $\begin{array}{l}\text { Scope } \\
\text { Artikel }\end{array}$ & Judul Artikel \\
\hline 1 & Muh. Fahrurrozi & Education & $\begin{array}{l}\text { Developing Economics Teaching Materials Using Android- } \\
\text { Based of Mit App Inventor Software for Student Learning } \\
\text { Independence }\end{array}$ \\
\hline 2 & Dharma Satrya HD & Education & The Discourse of Sasak's Art: From Tradition To Modernity \\
\hline 3 & Shahibul Ahyan & Education & $\begin{array}{l}\text { Mathematical literacy of ninth grade students in solving } \\
\text { PISA mathematics problems }\end{array}$ \\
\hline 4 & Maman Asrobi & Education & $\begin{array}{l}\text { Factors Determining Unsustainable English Learning on } \\
\text { EFL Learners }\end{array}$ \\
\hline 5 & Aswasulasikin & Education & $\begin{array}{l}\text { The Influence of Adolescent Soap Opera towards } \\
\text { Elementary Students Behavior }\end{array}$ \\
\hline 6 & $\begin{array}{l}\text { Dr.Hartini Haritani, } \\
\text { M.Pd. }\end{array}$ & Education & $\begin{array}{l}\text { The Correlation of Course-Undergraduate Research } \\
\text { Experience toward Critical Thinking Skill Laboratory }\end{array}$ \\
\hline 7 & Khirjan Nahdi & Education & $\begin{array}{l}\text { Inside Outside Circle: Learning Method and Early } \\
\text { Literation Of Children Age }\end{array}$ \\
\hline 8 & Fitri Aulia & Education & $\begin{array}{l}\text { The Occurrence of Mental Disorders in Adolescents with } \\
\text { Social-Emotional Disabilities and Intellectual Disabilities } \\
\text { because of Trauma }\end{array}$ \\
\hline
\end{tabular}

Keseluruhan artikel yang di-publish dapat diakses melalui: https://www.atlantispress.com/proceedings/psshers-19/articles; https://www.iijicc.net/index.php/volume-5-2019/178-vol5iss-6; dan https://iopscience.iop.org/issue/1742-6596/1539/1. Secara keseluruhan, dari 114 artikel yang ikut dalam Article Coaching Clinic, 67 artikel published di IOP JSC, 10 artikel published di Atlantis Press, dan 8 artikel published di IJICC, sehingga total 85 artikel berhasil dipublikasikan pada jurnal internasional bereputasi, atau 74,56\%. Secara kuantitatif program article coaching clinic ini sangat berhasil. Selanjutnya, secara kualitatif telah membawa pengaruh cukup besar dalam membangun budaya penulisan akademik di kalangan dosen Universitas Hamzanwadi.

\section{Simpulan}

Melalui beberapa tahap proses article coaching clinic dibuktikan bahwa proses publikasi artikel ilmiah dapat diakselarasi. Proses article coaching clinic dirancang tidak sebagaimana pelatihan biasa, ketika selesai tidak diikuti dengan proses pendampingan dan monitoring agenda selanjutnya. Kegiatan ini sukses hingga berhasil dipublikasikannya 85 artikel dari 114 artikel yang ikut clinic (74,56\%), karena beberapa alasan, yakni: pertama, materi yang ikut dalam clinic article seluruhnya (100\%) merupakan hasil penelitian dan ulasan/opini. Kedua, mater yang disajikan langsung berkaitan dengan kebutuhan peserta dalam hal penyusunan artikel sesuai standar jurnal bereputasi internasional. Ketiga, setiap tahapan proses setelah clinic article dipantau perkembangannya oleh seluruh tim fasilitator dengan tetap memberikan materi revisi sesuai standar reviewer jurnal.

\section{Referensi}

Alajami, A. (2020). Beyond originality in scientific research: Considering relations among originality, novelty, and ecological thinking. [Article]. Thinking Skills and Creativity, 38.

Bailey, S. (2003). Academic writing: A practical guide for students: Psychology Press.

B

otea, F., \& Popescu, I. (2020a). How to Write a Clinical Paper: Basics, Tips, Traps - Part I. [Article]. Chirurgia (Bucharest, Romania : 1990), 115(3), 314-322.

Botea, F., \& Popescu, I. (2020b). How to Write a Clinical Paper: Basics, Tips, Traps - Part II. [Article]. Chirurgia (Bucharest, Romania : 1990), 115(4), 432-440. 
Busse, C., \& August, E. (2020). How to Write and Publish a Research Paper for a Peer-Reviewed Journal. [Article]. Journal of Cancer Education.

Darmalaksana, W., \& Suryana, Y. (2018). Korespondensi dalam publikasi ilmiah. Jurnal Perspektif, 1(2).

Dikti, D. (2010). Pedoman beban kerja dosen dan evaluasi pelaksanaan tridharma perguruan tinggi. Jakarta: Kencana.

Djunaedi, F. (2015). Menulis Kreatif: Panduan Penulisan Ilmiah. Jakarta: Kencana.

Eddy, S. L. (2020). Recent Research in Science Teaching and Learning. [Article]. CBE life sciences education, $19(3)$, fe4.

Farid, M. (2017). Menulis Artikel Ilmiah: Proses Menemukan Ide Hingga Publikasi. Paper presented at the Makalah Seminar Penulisan Artikel Ilmiah, Perhimpunan Pelajar Indonesia (PPI) NPUST, NPUST Campus, Pingtung.

Fauzi, H., Aprianto, I., Amiruddin, A., \& Zulqarnain, Z. (2020). Strategi Pengembangan Mutu Perguruan TinggiI. Jurnal Ilmu Manajemen Terapan, 1(5), 416-424.

Gopee, N., \& Deane, M. (2013). Strategies for successful academic writing-Institutional and noninstitutional support for students. Nurse education today, 33(12), 1624-1631.

Kristanto, V. H. (2018). Metodologi Penelitian Pedoman Penulisan Karya Tulis Ilmiah:(KTI): Deepublish.

Lisek, J. (2020). 'To Write? What's This Torture For?' Bronia Baum's Manuscripts as Testimony to the Formation of a Writer, Activist, and Journalist. [Article]. Jewish History.

Mahendra, M. W., \& Dewi, N. P. R. P. (2017). The Use of Transition Signals in EFL Academic Writing Context: A Corpus Study. Jurnal Bahasa Lingua Scientia, 9(1), 87-100.

Nayyif Sujudi, N. (2020). Manajemen Dosen Perguruan Tinggi Swasta (Studi Tentang Penerapan Pendekatan Sistem Berbasis Life Cycle Dalam Manejemen Dosen Telkom University). Universitas Pendidikan Indonesia.

Nugrohoadhi, A. (2017). Pemanfaatan Publikasi Ilmiah di Perguruan Tinggi. LIBRARIA: Jurnal Ilmu Perpustakaan Dan Informasi, 97-114.

Panjehpour, \& Sorooshian, S. (2019). Content analysis of manuscript titles. [Article]. International Journal of Engineering and Advanced Technology, 8(6), 4531-4536.

Puljak, L., \& Sambunjak, D. (2020). Can Authorship be Denied for Contract Work? [Article]. Science and Engineering Ethics, 26(2), 1031-1037.

Reis, L. O. (2020). Quick beginners guide and tips on how to write a manuscript. [Article]. International Braz J Urol, 46(5), 822-824.

Ristekdikti. (2019). Pedoman Operasional Penilaian Angka Kredit Kenaikan Jabatan Akademik/Pangkat Dosen 2019.

Rumisek, L. A., \& Zemach, D. E. (2003). Academic writing from paragraph to essay: Macmillan.

Sasson, A., Okojie, O., Verano, R., Moshiri, M., Patlas, M. N., Hoffmann, J. C., et al. (2020). How to Read, Write, and Review the Imaging Literature. [Review]. Current Problems in Diagnostic Radiology.

Snyder, N., Foltz, C., Lendner, M., \& Vaccaro, A. R. (2019). How to Write an Effective Results Section. [Article]. Clinical Spine Surgery, 32(7), 295-296.

Weinstein, R. (2020). How to write a manuscript for peer review. [Review]. Journal of Clinical Apheresis, 35(4), 358-366.

Whang, Y. (2020). Reviewing a journal article with clarity and politeness: Key language tips for nonnative English-speaking reviewers. [Article]. Science Editing, 7(2), 204-208.

Wibawa, R., Kurniawati, W., \& Hardiansyah, H. (2020). Analisis Penggunaan Dana Sertifikasi Dosen Terhadap Peningkatan Mutu Perguruan Tinggi. Jurnal Teknologi Pendidikan: Jurnal Penelitian dan Pengembangan Pembelajaran, 4(2), 80-91. 